\title{
EFL Teachers' Perceptions on the Implementation of Mobile-Assisted Language Learning in Saudi Arabia During COVID-19: Challenges and Affordances
}

\author{
Norah Alghamdi \\ Albaha University, Saudi Arabia
}

\begin{abstract}
This study aimed to explore EFL teachers' perceptions regarding mobile-assisted language learning (MALL) in elementary schools in Saudi Arabia, including their attitudes, levels of proficiency, and challenges they experienced regarding the use of MALL. The study also sought to investigate whether EFL teachers' backgrounds have any significant impact on their perceptions of MALL. To this end, survey data were collected from 123 EFL teachers who have worked in elementary schools in Saudi Arabia. The results revealed teachers' positive perceptions of MALL, particularly during the COVID-19 pandemic. Overall, participants stated that mobile learning is beneficial and has the potential to support and enhance EFL teaching. Most EFL teachers reported that they did not have a sufficient level of skills/abilities required to develop MALL activities and cited some challenges they faced. The results also indicate a significant difference among participants' perceptions of MALL based on their professional development and teaching experience, but no difference based on their gender was found. These results indicate that placing a greater emphasis on offering professional development in MALL for Saudi EFL teachers could cultivate both greater proficiency and the ability to overcome challenges. This study concludes by providing recommendations on how to improve MALL implementation as well as directions for future research.
\end{abstract}

Index Terms-English as a Foreign Language (EFL), Mobile-Assisted Language Learning (MALL), COVID-19 pandemic

\section{INTRODUCTION}

The educational process has changed due to technological developments and the digital revolution of the 21 st century. Some researchers have stated that there have been transformations from the PC age to the age of mobilism in which teaching in the classroom has changed from an 'I Teach' teacher-centered method to 'We Learn' (Norris \& Soloway, 2011, p.3). Along the same lines, Prensky (2001) asserted that students today frequently use mobile phones and are described as digital natives. The mobile learning strategy is considered a recent trend of the digital age, and it can be used to enhance education (Chang \& Hwang, 2019). Mobile learning helps educators to enhance and promote learning and performance both inside and outside the school setting (Martin \& Ertzberger, 2013). When applied specifically to language learning, mobile learning is termed mobile-assisted language learning (MALL).

In early 2020, the World Health Organization announced that COVID-19 had become a global pandemic. As in other nations, the pandemic affected education in Saudi Arabia, as schools were shut down. As a result, the Saudi Ministry of Education decided to use online learning with students to help them complete their academic studies. This was the first time that online learning was utilized in Saudi K-12 schools. Currently, many Saudi EFL teachers and students use their mobile phones as a medium through which they learn.

However, research on mobile-assisted language learning (MALL) is still in its initial stages (Kukulska-Hulme \& Shield, 2008), and most of the current research on MALL focuses on its effectiveness and its impact on EFL learners (Hazaea \& Alzubi, 2016, Khubyari \& Narafshan, 2016). Saudi students' perspectives on using MALL have been discussed (Alkhudair, 2020), but there is a lack of research that examines teachers' perspectives on the utilization of MALL in Saudi schools. The current study aimed to fill this gap and contribute to the existing literature by exploring Saudi EFL teachers' perceptions regarding the use of MALL, including their attitudes, proficiency, and challenges that might hinder MALL implementation in Saudi schools. We also examined the factors that affect MALL adoption among EFL teachers.

\section{A. Significance of the Study}

The findings of this research provide researchers, curriculum designers, and policymakers with valuable information to understand the perceptions of EFL teachers regarding MALL in order to provide them with adequate professional development, effective instructional strategies, and interactive technology-based curriculums. Investigating the factors that affect teachers' perceptions regarding using MALL may help in understanding the process of its application and the 
challenges related to MALL. The results of this study are hoped to inspire educational institutions to provide effective and adequate programs of professional development that help to integrate MALL successfully in EFL teaching.

\section{B. Research Questions}

Q1. What are the attitudes of Saudi EFL teachers toward using MALL in EFL learning in elementary schools?

Q2. What are EFL elementary teachers' perceptions regarding their proficiency in developing MALL activities in EFL learning?

Q3. What are the perceptions of EFL teachers regarding the challenges of using MALL in EFL learning in elementary schools?

Q4. How do teachers' attitudes and perceptions regarding their proficiency vary based on gender, professional development, and teaching experience?

\section{LITERATURE REVIEW}

\section{A. Definition of MALL}

Computer-assisted language learning (CALL) is the first term that comes to mind when discussing the digitalization of language learning. MALL is viewed as a subset of CALL and a new phase in foreign language learning (Taj, Sulan, Sipra \&Ahmad, 2016). CALL-associated skills should be updated continuously to keep up with the rapid development of technology (Jarvis \& Achilleos, 2013). Thus, mobile phones are registered as a large growth segment in linguistic fields. Rahimi and Miri (2014) defined MALL as a technology-supported approach to second-language teaching and learning which has the potential to aid in the development of linguistic skills, as well as to further improve communication via recent advances in mobile technology.

\section{B. Benefits and Drawbacks of MALL}

Regarding MALL's associated benefits, mobile phones represent a modern technology that provides many opportunities for language learning. Mobile technology is viewed as a technique that provides students with many substantial advantages, including flexibility, portability/small size, low cost, and user friendliness (Miangah \& Nezarat, 2012). It also gives learners a chance to learn no matter where they are, supporting anywhere-and-anytime learning, as opposed to traditional learning. Due to their small size and weight, mobile phones can also be carried easily and taken to different places (Miangah \& Nezarat, 2012). Thus, mobile technology is non-restrictive and accommodating to personal circumstances. Moreover, a great deal of previous research has examined MALL's benefits in learning a language (Gharehblagh \& Nasri, 2020, Al-Jarrah, Talafhah \& Al-Jarrah, 2019, Chen, Jia \& An, 2020). It has been asserted that using mobile phones for language teaching purposes has been both successful and helpful, particularly in improving students' listening, reading, speaking, and writing skills. Krivoruchko et al. (2015) stated that MALL use increases learners' participation, engagement, and motivation in language learning. Moreover, Kukulska-Hulme and Viberg (2018) found that MALL helps to enhance communication and collaboration between students, allowing teachers to interact with all students simultaneously, potentially leading to more motivated and effective language teaching.

Despite the potential advantages, mobile learning is not without its drawbacks. Shortcomings cited as obstacles to MALL use as an educational approach include small screen size, an untrusted system of data storage, and limited presentation of graphics (Bachore, 2015). Chartrand (2016) also noted that dependence on the Internet is a problem for some EFL students. Considering that Internet connections can be unstable and may not always provide high transmission capacity, this may result in some students retaining less knowledge and understanding of the subject. Chartrand (2016) also stated that using mobile phones in the classroom could disrupt the learning process if irrelevant activities distract students from class content.

\section{Teachers Perceptions of Using MALL}

Positive perceptions and attitudes are the most powerful incentives for adopting MALL. Many studies have been conducted globally in an attempt to examine teachers' attitudes toward the implementation of mobile technology in their classes. For example, a study by Nariyati, Sudirman, and Pratiwi (2020) investigated EFL pre-service teachers' attitudes regarding MALL utilization. The participants expressed positive attitudes and believed that using mobile technology could enrich the language learning process. Due to such positive attitudes, the EFL teachers expressed a preference for MALL use in teaching English, in line with Nuraeni (2021) who found that most teachers had a positive attitude toward MALL use as a means of supporting classroom activities in teaching the English language during the COVID-19 pandemic. They believed that MALL was a good learning strategy to support their teaching process, perceiving it as a beneficial tool. They also hoped that EFL teachers would continue to use MALL in EFL teaching.

Nevertheless, other research $(\mathrm{Oz}, 2015)$ found that significant differences existed among Turkish EFL teachers in terms of their attitudes toward MALL use. This research also highlighted how female teachers expressed more positive attitudes and perceptions regarding MALL use in EFL classes as they believed that they could achieve increasingly satisfactory results using a mobile phone, as it removed time and space limitations and provided further opportunities for practicing and developing English language skills. Baek, Zhang, and Yun (2017) found that female EFL teachers 
were more positive than male ones in terms of attitudes. Additionally, more experienced educators (i.e., those with over 15 years of experience) expressed more positive perceptions of mobile learning than those who were less experienced. However, Dehkordi (2018) found no significant differences between male and female perceptions. Both expressed positive attitudes toward the use of MALL in the EFL learning process.

It is crucial to understand teachers' perspectives regarding applying MALL to teaching in EFL classrooms, particularly in terms of their proficiency and efficacy in developing MALL activities in EFL learning. According to Bandura (1977), the term 'self-efficacy' encompasses individuals' beliefs in their abilities as well as whether they possess the skills needed to complete tasks. Thus, teachers with high efficacy use instructional strategies that motivate students to learn and overcome the obstacles they encounter. Khan, Radzuan, Shahbaz and Ibrahim (2018) found that most Saudi university instructors lack the knowledge and skillset needed to develop and implement MALL activities. Most participants reported that using mobile devices can help to facilitate EFL learning, but some indicated that mobile phones cannot support EFL teaching. Many EFL educators reported inefficiencies among learners using mobile phones for academic purposes, with small screen sizes and unstable Internet connectivity cited as the key challenges in MALL use. In Dashtestani's (2013) study, EFL teachers reported that they needed to improve their skills to develop MALL activities. These findings also suggest that they encountered some challenges with MALL use, which might explain non-use of mobile devices for EFL teaching. These challenges include using mobile devices for non-educational purposes, students' lack of knowledge on how to use mobile device for academic purposes, the high cost of Internet connections, and slow Internet speeds. As the literature review indicates, very few studies have examined MALL use from Saudi EFL teachers' perspectives, as the COVID-19 crisis was the first-time online learning was used in Saudi K-12 schools, particularly in elementary schools. This study attempted to fill the aforementioned research gap by examining EFL teachers' perceptions of MALL use in elementary schools that potentially impact MALL implementation.

\section{METHODS}

To answer the present study's research questions and collect meaningful information about Saudi EFL teachers' perceptions about MALL use, this study used a quantitative design for the data collection, data analysis, and interpretation of the findings.

\section{A. Instruments}

This study used a survey developed by Khan et al. (2018) from the pre-existing literature. Essential changes were implemented in the questionnaire to match the Saudi EFL context. The survey was valid, as it was sent to five researchers and university teachers in the Saudi context, and appropriate corrections were made in accordance with their comments (Khan et al., 2018).

The survey included 4 parts and 25 items, with the first part focusing on EFL teachers' demographics, including gender, teaching experience, and whether they had received professional development training for MALL. The second part entailed teachers' attitudes regarding MALL use. The third part included questions about the challenges of MALL integration. The last part focused on determining EFL teachers' ability to develop MALL activities. The second and third parts comprised four-point Likert scales with the following options: (1) strongly disagree; (2) disagree; (3) agree; and (4) strongly agree. The fourth part comprised a scale with five possible responses for each question: (1) not proficient; (2) fairly proficient; (3) undecided; (4) proficient; and (5) very proficient. In Khan et al.'s (2018) study, three questionnaire sections (teachers' attitudes, their ability to develop MALL activities, and challenges with MALL use) demonstrated reliability through Cronbach's alpha scores of $0.86: 0.83,0.79$, and 0.86 , respectively. In the present study, the Cronbach's alpha scores for these three sections were $0.69,0.85$, and 0.97 , respectively.

\section{B. Data Collection and Analysis}

The survey was uploaded to Google Forms and sent to EFL teachers via various modes of social media. The data were collected in the spring semester of 2021 and imported into SPSS 27.0 for analysis. Descriptive statistics (mean and standard deviation) were computed (for the first, second, and third questions) to examine Saudi EFL teachers' attitudes, perceptions of their proficiency, and challenges in using MALL. For the fourth question, a one-way multivariate analysis of variance (MANOVA) was used to examine whether difference existed among EFL teachers' attitudes and perceptions regarding their proficiency in MALL use, specifically based on their gender, teaching experience, and professional development, which were independent variables. Gender comprised two groups: male and female. Professional development comprised two groups: teachers who had received MALL professional development and those who had not received it. Three groups were established for teaching experience: 0-10 years; 11-20 years; and 21-30 years. The dependent variables were teachers' attitudes toward MALL and perceptions of their proficiency in MALL use.

\section{Participants}

The population sampled in this study consisted of EFL teachers from elementary schools in Saudi Arabia. The random method of sampling was used for the selection of the participants in this study. An online survey was distributed 
to 205 EFL teachers via a link; 123 participants returned the survey, with a response rate of $60 \%$, which is a good sample size for data analysis purposes.

The results of the descriptive statistics indicated that of the 123 participants who took the survey, 79 were female and 44 were male. The majority of the participants in this study (39.8\%) reported that they had 11 to 20 years of teaching experience, followed by participants with 0 to 10 years of teaching experience $(35.8 \%)$ and participants with 21 to 30 years of teaching experience (24.4\%). Of the 123 respondents, 76 of the teachers had not received professional development training for MALL, and 47 had received professional development training for MALL (Table 1).

TABLE 1

PARTICIPANT CHARACTERISTICS

\begin{tabular}{llll}
\hline Measure & Item & Total Number & Percentage \\
\multirow{2}{*}{ Gender } & Male & 44 & $35.8 \%$ \\
& Female & 79 & $64.2 \%$ \\
\multirow{2}{*}{ Years of teaching experience } & $0-10$ & 44 & $35.8 \%$ \\
& $11-20$ & 49 & $39.8 \%$ \\
\multirow{2}{*}{ MALL Professional Development } & $21-30$ & 30 & $24.4 \%$ \\
& Yes & 76 & $62 \%$ \\
\hline
\end{tabular}

\section{RESULTS}

\section{A. Attitudes of EFL Teachers toward Using MALL}

The first research question was designed to examine Saudi EFL teachers' attitudes toward using mobile-assisted language learning to help facilitate EFL learning in elementary schools. A high score indicates a positive attitude toward MALL, while a low score indicates a negative attitude toward MALL. As seen in Table 2, the total mean for Saudi EFL teachers' attitudes toward MALL use was 3.012, indicating that Saudi EFL teachers have positive attitudes toward MALL utilization in elementary schools. Most of the teachers also expressed favorable attitudes regarding the advantages of MALL. The results also found that the statement "Mobile phones can be used to teach/learn different language skills" elicited the highest rating, with a mean of 3.10, while "Mobile phone usage can create collaborative learning environments" elicited the lowest rating, with a mean of 2.98 (Table 2).

TABLE 2

ATTITUDES OF EFL TEACHERS TOWARD MALL

\begin{tabular}{lll}
\hline Item & Mean & St. Deviation \\
\hline Mobile phone usage will facilitate the language learning process & 3.05 & 0.839 \\
Portability is a key feature of mobile phones & 3.02 & 0.779 \\
Mobile phone usage can create collaborative learning environments & 2.98 & 0.839 \\
Multimedia attributes of mobile phones are useful for EFL teaching & 3.02 & 0.839 \\
Mobile phones can provide scaffolding for each learner & 3.01 & 0.830 \\
Mobile phones can be used to teach/learn different language skills & 3.10 & 0.844 \\
Mobile phone integration is cost effective in EFL teaching & 3.05 & 0.768 \\
Mobile phones usage for language teaching is time efficient & 3.00 & 0.820 \\
Mobile phones can be connected to the Internet at any time & 3.04 & 0.834 \\
Mobile phones can facilitate learning for ESL learners & 3.02 & 0.789 \\
\hline
\end{tabular}

\section{B. EFL Teachers' Perceptions Regarding Their Proficiency in Developing MALL Activities}

The total mean for the teachers' perceptions regarding their ability to develop and use MALL activities was 2.48, indicating that most Saudi EFL teachers did not have a high level of proficiency in using MALL and lacked the skills/abilities necessary to develop MALL activities. The results also show that the item "Ability to evaluate MALL software tools" elicited the highest rating from respondents, with a mean of 2.58, while the lowest-rated item was "Designing and creating MALL activities", with a mean of 2.44 (Table 3).

TABLE 3

EFL TEACHERS' PERCEPTIONS REGARDING THEIR PROFICIENCY

\begin{tabular}{lll}
\hline Item & Mean & St. Deviation \\
\hline Designing and creating MALL activities & 2.44 & 1.175 \\
Ability to adapt teaching styles to MALL & 2.48 & 1.203 \\
Ability to evaluate MALL software tools & 2.58 & 1.192 \\
ICT knowledge to use mobile phones for EFL & 2.45 & 1.175 \\
Ability to use MALL software tools & 2.56 & 1.255 \\
\hline
\end{tabular}

\section{EFL Teachers'Perceptions on the Challenges of Using MALL}

The Saudi EFL teachers showed agreement regarding most of the challenges of MALL usage in elementary schools, including the following perceived challenges to the implementation of MALL: students' non-use of mobile phones for academic purposes, students' lack of skill/knowledge to use mobile phones for academic purposes, internet connectivity 
obstacles, small screen size, slow internet speed, and lack of MALL activities and software tools. The findings show that the statement "Students' lack of skill/knowledge to use mobile phones for academic purposes" had the highest rating with a mean of 3.20; the lowest-rated statement was "Incompatibility of mobile software with language teaching/learning" with a mean of 2.37 (Table 4).

TABLE 4

EFL TEACHERs’ PeRCEPTIONS ON THE ChaLlENGES OF Using MALL

\begin{tabular}{lll}
\hline Item & Mean & Std. Deviation \\
\hline The small screen size of mobile phones & 3.04 & 0.794 \\
Internet or data speed & 3.00 & 0.698 \\
Internet connectivity obstacles & 3.15 & 0.651 \\
Students' non-use of mobile phones for academic purposes & 3.18 & 0.794 \\
Price of mobile phones & 2.50 & 0.762 \\
High cost of data bundles or Wi-Fi Charges & 2.37 & 0.704 \\
Students' lack of skills to use mobile for academic purposes & 3.20 & 0.821 \\
Incompatibility of mobile software with language teaching & 2.37 & 0.716 \\
Students' resistance to the use of mobile for academic purposes & 2.51 & 0.704 \\
Lack of mobile-based language learning software and activities & 2.58 & 0.694
\end{tabular}

\section{Teachers'Attitudes and Perceptions Regarding Their Proficiency Based on Professional Development}

A MANOVA model was used to examine whether significant differences existed in teachers' attitudes toward MALL, as well as their perceptions regarding their proficiency based on receiving professional development. A statistically significant difference was found in teachers' attitudes toward using MALL and perceptions of their MALL proficiency based on receiving professional development $\left(\mathrm{F}[2,120]=37.14, p<0.0005\right.$; Wilk's $\Lambda=0.618$, partial $\left.\eta^{2}=0.38\right)$. As for teachers' attitudes, the EFL teachers who received professional development in general education scored higher than those who did not receive it, with a difference of 6.66 between them. This finding was found to be statistically significant $\left(F[1,121]=34.16, p<0.0005\right.$; partial $\left.\eta^{2}=0.22\right)$. As for teachers' perceptions regarding their proficiency, EFL teachers who received professional development scored higher than those who did not receive it, with a difference of 6.08 between them. This finding was found to be statistically significant $\left(\mathrm{F}[1,121]=48.20, p<0.0005\right.$; partial $\eta^{2}=$ $0.28)$ (Table 5).

TABLE 5

MANOVA PROFESSIONAL DEVELOPMENT MODEL

\begin{tabular}{|c|c|c|c|c|c|c|c|}
\hline \multicolumn{8}{|l|}{ Multivariate Test } \\
\hline Effect & & Value & $\mathrm{F}$ & Hypothesis df & Error df & Sig & $\begin{array}{l}\text { Partial } \\
\text { Eta Squared }\end{array}$ \\
\hline \multirow{4}{*}{$\begin{array}{l}\text { Professional } \\
\text { development }\end{array}$} & Pillai's Trace & 0.382 & $37.135^{b}$ & 2.000 & 120.000 & 0.000 & 0.382 \\
\hline & Wilk's Lambda & 0.619 & $37.135^{b}$ & 2.000 & 120.000 & 0.000 & 0.382 \\
\hline & Hotelling's Trace & 0.619 & $37.135^{b}$ & 2.000 & 120.000 & 0.000 & 0.382 \\
\hline & Roy's Largest Root & 0.619 & $37.135^{b}$ & 2.000 & 120.000 & 0.000 & 0.382 \\
\hline \multicolumn{8}{|c|}{ Test of Between-Subjects Effects } \\
\hline Source & DV & $\begin{array}{l}\text { Type III Sum } \\
\text { of Squared }\end{array}$ & $\mathrm{df}$ & Mean Squared & $\mathrm{F}$ & Sig. & $\begin{array}{l}\text { Partial } \\
\text { Eta Squared }\end{array}$ \\
\hline \multirow{2}{*}{ Corrected Model } & \multirow{2}{*}{ Attitude } & $1363.253^{\mathrm{a}}$ & 1 & 1363.253 & 34.655 & 0.000 & 0.223 \\
\hline & & $1136.100^{b}$ & 1 & 1136.100 & 48.188 & 0.000 & 0.285 \\
\hline \multirow{2}{*}{ Intercept } & Attitude & $112,137.757$ & 1 & $112,137.757$ & 2850.61 & 0.000 & 0.959 \\
\hline & Proficiency & $20,699.872$ & 1 & $20,699.872$ & 877.996 & 0.000 & 0.879 \\
\hline Professional & Attitude & 1363.253 & 1 & 1363.253 & 34.655 & 0.000 & 0.223 \\
\hline Development & Proficiency & 1136.1 & 1 & 1136.1 & 48.188 & 0.000 & 0.285 \\
\hline \multirow{2}{*}{ Error } & Attitude & 4759.917 & 121 & 39.338 & & & \\
\hline & Proficiency & 2852.729 & 121 & 23.576 & & & \\
\hline \multirow{2}{*}{ Total } & Attitude & $117,725.000$ & 123 & & & & \\
\hline & Proficiency & $24,465.000$ & 123 & & & & \\
\hline Corrected & Attitude & 6123.171 & 122 & & & & \\
\hline Total & Proficiency & 3988.829 & 122 & & & & \\
\hline
\end{tabular}

\section{E. Teachers' Attitudes and Perceptions Regarding Their Proficiency Based on Gender}

A MANOVA model was also conducted to investigate whether significant differences existed in teachers' attitudes toward MALL, as well as their perceptions regarding their proficiency based on based on their gender. There was no significant difference in teachers' attitudes and perceptions regarding their proficiency based on their gender, $(\mathrm{F}[2,120]$ $=1.83, p=0.165$; Wilk's $\Lambda=0.970$, partial $\left.\eta^{2}=0.030\right)$. As for teachers' attitudes, the result was insignificant $(\mathrm{F}[1,121]$ $=3.1, p=0.083$; partial $\left.\eta^{2}=0.025\right)$. As for teachers' perceptions regarding their proficiency/ability, the result was also insignificant $\left(\mathrm{F}[1,121]=1.71, p=0.193\right.$; partial $\left.\eta^{2}=0.014\right)$ (Table 6). 
TABLE 6

MONOVA GENDER MODEL

\begin{tabular}{|c|c|c|c|c|c|c|c|}
\hline \multicolumn{8}{|c|}{ Multivariate Test } \\
\hline Effect & & Value & $\mathrm{F}$ & $\begin{array}{l}\text { Hypothesis } \\
\text { df }\end{array}$ & Error df & Sig & $\begin{array}{l}\text { Partial } \\
\text { Eta Squared }\end{array}$ \\
\hline \multirow{4}{*}{ Gender } & Pillai’s Trace & 0.030 & $1.830^{\mathrm{b}}$ & 2.000 & 120.000 & 0.165 & 0.030 \\
\hline & Wilk's Lambda & 0.970 & $1.830^{\mathrm{b}}$ & 2.000 & 120.000 & 0.165 & 0.030 \\
\hline & Hotelling's Trace & 0.030 & $1.830^{\mathrm{b}}$ & 2.000 & 120.000 & 0.165 & 0.030 \\
\hline & Roy's Largest Root & 0.030 & $1.830^{\mathrm{b}}$ & 2.000 & 120.000 & 0.165 & 0.030 \\
\hline \multicolumn{8}{|c|}{ Test of Between-Subjects Effect } \\
\hline Source & DV & $\begin{array}{l}\text { Type III Su } \\
\text { Squares }\end{array}$ & $\mathrm{fff}_{\mathrm{df}}$ & Mean Square & $\mathrm{F}$ & Sig. & $\begin{array}{l}\text { Partial } \\
\text { Eta Squared }\end{array}$ \\
\hline \multirow{2}{*}{ Corrected Model } & Attitude & $151.191^{\mathrm{a}}$ & 1 & 151.191 & 3.063 & 0.083 & 0.025 \\
\hline & Proficiency & $55.791^{\mathrm{b}}$ & 1 & 55.791 & 1.716 & 0.193 & 0.014 \\
\hline \multirow{2}{*}{ Intercept } & Attitude & $100,336.557$ & 1 & $100,336.557$ & 2032.948 & $<0.001$ & 0.944 \\
\hline & Proficiency & $18,239.596$ & 1 & $18,239.596$ & 561.142 & $<0.001$ & 0.823 \\
\hline \multirow{2}{*}{ Gender } & Attitude & 151.191 & 1 & 151.191 & 3.063 & 0.083 & 0.025 \\
\hline & Proficiency & 55.791 & 1 & 55.791 & 1.716 & 0.193 & 0.014 \\
\hline \multirow{2}{*}{ Error } & Attitude & 597.979 & 121 & 49.355 & & & \\
\hline & Proficiency & 3933.038 & 121 & 32.504 & & & \\
\hline \multirow{2}{*}{ Total } & Attitude & 17,725 & 123 & & & & \\
\hline & Proficiency & 24,465 & 123 & & & & \\
\hline Corrected & Attitude & 6123.171 & 122 & & & & \\
\hline Total & Proficiency & 3988.829 & 122 & & & & \\
\hline
\end{tabular}

\section{F. Teachers'Attitudes and Perceptions Regarding Their Proficiency Based on Teaching Experience}

A MANOVA model was used to examine whether significant differences in teachers' attitudes toward MALL existed, as well as their perceptions regarding their proficiency based on the years of teaching experience (three groups: $0-10$ years of experience, 11-20 years of experience, and 21-30 years of experience). There was a statistically significant difference in teachers' attitudes and perceptions regarding their proficiency based on teaching experiences, Wilk's $\Lambda=$ $0.626, p<0.0005$. The findings of the MANOVA tests are as follows: teachers' attitudes $(\mathrm{F}[1,121]=25.49, p<0.0005$; partial $\left.\eta^{2}=0.29\right)$ and teachers' perceptions regarding their proficiency $\left(\mathrm{F}[1,121]=14.17, p<0.0005\right.$; partial $\left.\eta^{2}=0.19\right)$ (Table 7).

TABLE 7

MANOVA TEACHING EXPERIENCE MODEL

\begin{tabular}{|c|c|c|c|c|c|c|c|}
\hline \multicolumn{8}{|l|}{ Multivariate Test } \\
\hline Effect & & Value & $\mathrm{F}$ & Hypothesis df & Error df & Sig & $\begin{array}{l}\text { Partial } \\
\text { Eta Squared }\end{array}$ \\
\hline \multirow{4}{*}{ Teaching Experience } & Pillai’s Trace & 0.378 & 13.992 & 4.000 & 240.000 & 0.000 & 0.189 \\
\hline & Wilk's Lambda & 0.626 & $15.679^{b}$ & 4.000 & 238.000 & 0.000 & 0.209 \\
\hline & Hotelling's Trace & 0.589 & 17.379 & 4.000 & 236.000 & 0.000 & 0.228 \\
\hline & Roy's Largest Root & 0.576 & $34.585^{\mathrm{c}}$ & 2.000 & 120.000 & 0.000 & 0.366 \\
\hline \multicolumn{8}{|c|}{ Tests of Between-Subjects Effects } \\
\hline Source & DV & $\begin{array}{l}\text { Type III Sum } \\
\text { Squares }\end{array}$ & $\mathrm{f}_{\mathrm{df}}$ & Mean Square & $\mathrm{F}$ & Sig. & $\begin{array}{l}\text { Partial } \\
\text { Eta Squared }\end{array}$ \\
\hline \multirow{2}{*}{ Corrected Model } & Attitude & $1826.145^{\mathrm{a}}$ & \multirow{2}{*}{2} & 913.072 & 25.499 & 0.000 & 0.298 \\
\hline & Proficiency & $762.165^{b}$ & & 381.083 & 14.173 & 0.000 & 0.191 \\
\hline \multirow{2}{*}{ Intercept } & Attitude & $109,850.326$ & 1 & $109,850.32$ & 3067.712 & 0.000 & 0.962 \\
\hline & Proficiency & $20,787.186$ & 1 & $20,787.186$ & 773.078 & 0.000 & 0.866 \\
\hline \multirow{2}{*}{ Teaching Experience } & Attitude & 1826.145 & 2 & 913.072 & 25.499 & 0.000 & 0.298 \\
\hline & Proficiency & 762.165 & 2 & 381.083 & 14.173 & 0.000 & 0.191 \\
\hline \multirow{2}{*}{ Error } & Attitude & 4297.026 & 120 & 35.809 & & & \\
\hline & Proficiency & 3226.664 & 120 & 26.889 & & & \\
\hline \multirow{2}{*}{ Total } & Attitude & 3226.664 & 123 & & & & \\
\hline & Proficiency & 117,725 & 123 & & & & \\
\hline Corrected & Attitude & 6123.171 & 122 & & & & \\
\hline Total & Proficiency & 3988.829 & 122 & & & & \\
\hline
\end{tabular}

In order to investigate where these significant differences occurred, Tukey post hoc tests were conducted on all four factors. Tukey post hoc comparisons revealed that for teachers' attitudes, the results of the tests indicate that those who had 21-30 years of experience showed significantly higher values than those who had from 0 to 10 years of experience (mean diff. $=9.52, p$-value $=0.000)$. Additionally, the values among those who had $11-20$ years of experience were significantly higher than those who had from 0 to 10 years of experience (mean diff. $=6.50, p$-value $=0.000$ ). However, those who had 11-20 years of experience did not significantly differ from those who had 21-30 $(p$-value $=0.079)$.

As for teachers' perceptions of their ability, the results of the tests indicated that those who had 21-30 years of experience showed significantly higher values than those who had 0 to 10 years of experience (mean diff. $=6.51$, 
$p$-value $=0.000$ ), and those who had $11-20$ years of experience (mean diff. $=3.51, p$-value $=012$ ). Additionally, those who had 11-20 years of experience showed significantly higher values than those who had from 0 to 10 years of experience $($ Mean diff. $=3.00, p$-value $=0.017)$ (Table 8$)$.

TABLE 8

POST HOC TEST (TUKEY HSD)

\begin{tabular}{|c|c|c|c|c|c|c|c|}
\hline \multirow{2}{*}{ Dependent Variable } & \multirow{2}{*}{\multicolumn{2}{|c|}{ Teaching Experience }} & \multirow{2}{*}{ Mean Difference } & \multirow{2}{*}{ Std. Error } & \multirow{2}{*}{ Sig } & \multicolumn{2}{|c|}{$95 \%$ Confidence Interval } \\
\hline & & & & & & Lower & Upper \\
\hline \multirow{6}{*}{ Attitude } & \multirow{2}{*}{$0-10$ years } & $11-20$ years & $-6.5097 *$ & 1.24283 & 0.000 & -9.4592 & -3.5603 \\
\hline & & $21-30$ years & $-9.5288 *$ & 1.41684 & 0.000 & -12.891 & -6.1664 \\
\hline & \multirow{2}{*}{$11-20$ years } & $0-10$ years & $6.5097 *$ & 1.24283 & 0.000 & 3.5603 & 9.4592 \\
\hline & & $21-30$ years & -3.019 & 1.38723 & 0.079 & -6.3111 & 0.2731 \\
\hline & \multirow{2}{*}{$21-30$ years } & $0-10$ years & $9.5288 *$ & 1.41684 & 0.000 & 6.1664 & 12.8912 \\
\hline & & $11-20$ years & 3.019 & 1.38723 & 0.079 & -2.731 & 6.3111 \\
\hline \multirow{6}{*}{ Proficiency } & \multirow{2}{*}{$0-10$ years } & $11-20$ years & $-3.0088 *$ & 1.07697 & 0.017 & -5.5646 & -0.453 \\
\hline & & $21-30$ years & $-6.5197 *$ & 1.22776 & 0.000 & -9.4334 & -3.606 \\
\hline & \multirow{2}{*}{$11-20$ years } & $0-10$ years & $3.0088 *$ & 1.07697 & 0.017 & 0.453 & 5.5646 \\
\hline & & $21-30$ years & $-3.5109 *$ & 1.2021 & 0.012 & -6.3636 & -0.6581 \\
\hline & \multirow{2}{*}{$21-30$ years } & $0-10$ years & $6.5197 *$ & 1.22776 & 0.000 & 3.606 & 9.4334 \\
\hline & & $11-20$ years & $3.5109 *$ & 1.2021 & 0.012 & 0.6581 & 6.3636 \\
\hline
\end{tabular}

* The mean difference is significant.

\section{DISCUSSION}

This study examined Saudi EFL teachers' attitudes toward MALL, as well as perceptions regarding MALL proficiency and challenges in elementary schools. Additionally, the study investigated whether any of these demographics (gender, teaching experience, and professional development) have any effect on EFL teachers' perceptions regarding MALL utilization. The results demonstrated that teachers generally had a positive attitude toward utilizing MALL in elementary schools in Saudi Arabia. The teachers agreed on using mobile phones for teaching and integration, stating that using mobile phones offers many advantages, including "portability, learning opportunities, multimedia functions, accessibility, scaffolding, availability, and connectivity of data." After MALL was initially applied to teaching lessons during the COVID-19 pandemic, EFL teachers reported an overall positive attitude toward MALL use among elementary students, and they viewed it as beneficial for learning activities. These results concerning the first research question are in line with research on teachers' attitudes toward MALL use in other contexts (Nariyati et al., 2020, Nuraeni, 2021), further confirming teachers' positive attitudes toward MALL use to support classroom activities, particularly those concerning learning the English language in the middle of the COVID-19 pandemic.

The findings also indicated that most Saudi teachers did not have sufficient abilities or skills to develop MALL activities in EFL learning, which is in line with other research (Dashtestani, 2013, Khan et al., 2018). Dashtestani (2013) highlighted that educational institutions should provide EFL teachers with the ICT skills needed for the proper implementation and use of MALL. Based on Bandura's theory, teachers with high efficacy use new instructional strategies (such as MALL) that motivate students to learn (Bray-Clark \& Bates, 2003). According to Kent and Giles (2016), teachers with low levels of self-efficacy and skills in using new methods such as ICT will experience a negative effect on their ability to implement such methods in their classrooms. Therefore, providing Saudi teachers in elementary schools with MALL training and professional development training is key to improving MALL utilization proficiency in EFL teaching.

Considering that Saudi teachers felt that their proficiency in using MALL in EFL teaching was low, they inevitably experienced some challenges that affected MALL utilization. As Bandura (1977) stated, those with high self-efficacy can overcome challenges and difficulties. EFL teachers in elementary schools reported that they encountered some difficulties, including students' not using mobile phones for academic purposes, a lack of skills in the use of mobile phones for academic purposes among students, Internet connectivity obstacles, and lack of MALL activities and software tools. These findings are consistent with previous studies (Khan et al., 2018, Bakhsh, 2015 \&Bozorgian, 2018) indicating that EFL teachers encountered some of these difficulties while implementing MALL. Therefore, placing a greater emphasis on and working toward offering MALL training for Saudi EFL teachers could potentially cultivate both greater self-efficacy in using MALL and the ability to overcome challenges.

The results demonstrated no significant gender-based differences among the participants in terms of their attitudes toward MALL and their perceptions regarding their MALL proficiency. Male and female teachers both had positive perceptions of MALL use in EFL teaching and learning. However, a portion of this research was inconsistent with these findings and suggested that gender affected teachers' attitudes toward and perceptions of MALL (Nuraeni, 2021 \& Oz, 2015). Females reported stronger positive perceptions regarding mobile learning in EFL teaching as they believed that they could reach increasingly satisfactory results through its use.

The current study's results revealed a difference among participants in their attitudes and perceptions toward MALL utilization based on their professional development and teaching experience. The EFL teachers who received professional development training were more positive than teachers who did not receive it regarding both their attitudes 
toward MALL and perceptions of their proficiency in developing MALL activities. As reported previously, 76 participants had not previously attended MALL training, i.e., not all Saudi EFL teachers in elementary schools receive MALL training, which can affect their MALL practice. This finding is consistent with those of previous studies reporting that receiving training impacts teacher perception, particularly regarding MALL utilization (Nazari \& Xodabande, 2020). Thus, continued MALL-related training courses, conferences, and workshops can be effective in supporting teachers in MALL's use, which could lead to more successful MALL implementation. As Carless (1999) stated, "Without sufficient retraining, even teachers initially enthusiastic about an innovation method can become frustrated by problems in implementation and eventually turn against the project." (p. 23).

Moreover, these findings indicate that Saudi EFL teachers' teaching experience significantly affects both their attitudes and perceptions regarding MALL in elementary schools. EFL teachers who had 21-30 years of experience were more positive than those with less teaching experience concerning their attitudes toward MALL and their perceptions of their proficiency in developing MALL activities. These results align with those of Baek et al.'s (2017) study that found EFL teachers with more than 15 years of teaching experience showed higher positive perceptions regarding mobile MALL use than other less experienced groups. According to Rosa (2016), experienced EFL teachers are more positive toward using technology than novice teachers and shows more support regarding the advantages of technology in language teaching.

\section{CONCLUSION}

MALL is the latest method to emerge in language learning and entails the use of applications to support students' learning, particularly during the COVID-19 pandemic (Nuraeni, 2021). As elementary schools were required to shift to online learning and MALL utilization, this study focused on Saudi teachers' perspectives, particularly on MALL utilization among English -language teachers. Therefore, it is important that Saudi policymakers, curriculum designers, and educators take into account teachers' perceptions when applying changes to teaching techniques and methods. It is clear that teachers play a crucial role in effectively applying MALL in practice, and, for this reason, it is essential to consider their views on it. Generally, teachers in Saudi elementary schools tend to express positive attitudes toward MALL use in EFL classrooms.

To implement MALL effectively, it is vital to consider the context in which it operates. Thus, the Ministry of Education should attempt to minimize constraints and challenges associated with MALL adoption in the Saudi context and increase teachers' proficiency levels, including their ability to develop MALL activities, particularly considering that they do not possess the required skills. According to Dashtestani (2013) and Nazari and Xodabande (2020), a need exists to provide EFL teachers with the necessary skills by coaching them on the use of technology (such as MALL) in language teaching, both practically and theoretically. Therefore, Saudi EFL teachers should attend pedagogical and practical training for the design and evaluation of MALL activities. The Ministry of Education should organize successive, continued, and practical MALL workshops intended to develop and design MALL activities and tasks. This would be a better approach to encourage language teachers to participate in collaborative projects on MALL implementation. Furthermore, a wide range of MALL software programs should be available to EFL teachers, facilitating access to effective and reliable MALL activities and software programs.

Conducting this study provided an opportunity to determine the literature gaps in this topic, as well as to recommend possible directions for future research. Based on a review of the literature, there is a lack of research exploring Saudi EFL teachers' perceptions of MALL implementation in K-12 schools. In the future, this study could be replicated, but it could include teachers' perceptions on MALL use at all school levels, rather than solely elementary schools. Researchers could potentially also study Saudi EFL teachers' MALL perceptions and practices using different methodologies, such as a qualitative method or mixed methods. Researchers should investigate both EFL teachers and students' perceptions regarding actual MALL practices, as this would help to examine the difficulties and challenges potentially affecting both parties. The present study's results contribute to the field by improving EFL teaching.

\section{REFERENCES}

[1] Al-Jarrah, J. M., Talafhah, R. H., \& Al-Jarrah, T. M. (2019). ESL teacher perceptions of using educational mobile applications to develop the language skills of ESL elementary school students. European Journal of Foreign Language Learning, 4(1), 65-86. doi.10.46827/ejfl.v0i0.2275

[2] Alkhudair, R. Y. (2020). Mobile assisted language learning in Saudi EFL classrooms: Effectiveness, perception, and attitude. Theory and Practice in Language Studies, 10(12), 1620-1627. doi.10.17507/tpls.1012.16

[3] Bachore, M. M. (2015). Language learning through mobile technologies: An opportunity for language learners and teachers. Journal of Education and Practice, 6(31), 50-53.

[4] Baek, Y., Zhang, H., \& Yun, S. (2017). Teachers' attitudes toward mobile learning in Korea. The Turkish Online Journal of Educational Technology, 16(1), 154-163.

[5] Bakhsh, S. S. H. (2015). Mobile learning adoption by language instructors in Taibah University. Educational Research International, 4(5), 110-143.

[6] Bandura, A. (1977). Self-Efficacy: Toward a unifying theory of behavioral change. Psychological Review, 84(2), $191-215$. doi.10.1037/0033-295X.84.2.191

[7] Bozorgian, H. (2018). Teachers' attitudes towards the use of MALL instruction in Iranian EFL context. The International 
Journal of Humanities, 25(3), 1-18.

[8] Bray-Clark, N., \& Bates, R. (2003). Self-efficacy beliefs and teacher effectiveness: Implications for professional development. Professional Educator, 26(1), 13-22.

[9] Carless, D. R. (1999). Large-scale curriculum change in Hong Kong. In C. Kennedy, P. Doyle, \& C. Goh (Eds.), Exploring Change in English Language Teaching (pp. 19-29). Macmillan Heinemann English Language Teaching, Oxford, United States.

[10] Chang, C. Y., \& Hwang, G. J. (2019). Trends in digital game-based learning in the mobile era: A systematic review of journal publications from 2007 to 2016. International Journal of Mobile Learning and Organisation, 13(1), 68-90. doi.10.1504/IJMLO.2019.096468

[11] Chartrand, R. (2016). Advantages and disadvantages of using mobile devices in a university language classroom. Bulletin of the Institute of Foreign Language Education Kurume University, 23, 1-13.

[12] Chen, Z., Chen, W., Jia, J., \& An, H. (2020). The effects of using mobile devices on language learning: A meta-analysis. Educational Technology Research and Development, 68(4), 1769-1789.

[13] Dashtestani, R. (2013). Implementing mobile-assisted language learning (MALL) in an EFL context: Iranian EFL teachers' perspectives on challenges and affordances. Jalt CALL Journal, 9(2), 149-168.

[14] Dehkordi, M. E. (2018). Iranian male and female EFL learners' perceptions toward the use of mobile assisted language learning. Journal of Applied Linguistics and Language Research, 5(3), 56-66.

[15] Gharehblagh, N. M., \& Nasri, N. (2020). Developing EFL elementary learners' writing skills through mobile-assisted language learning (MALL). Teaching English with Technology, 20(1), 104-121.

[16] Hazaea, A. N., \& Alzubi, A. A. (2016). The effectiveness of using mobile on EFL learners' reading practices in Najran University. English language teaching, 9(5), 8-21.

[17] Jarvis, H. A., \& Achilleos, M. (2013). From computer assisted language learning (CALL) to mobile assisted language use. Tesl-ej, 16(4), 1-18.

[18] Kent, A. M., \& Giles, R. M. (2017). Preservice teachers' technology self-efficacy. SRATE Journal, 26(1), 9-20.

[19] Khan, R. M. I., Radzuan, N. R. M., Shahbaz, M., \& Ibrahim, A. H. (2018). EFL instructors' perceptions on the integration and implementation of MALL in EFL Classes. International Journal of Language Education and Applied Linguistics, 39-50. doi.10.15282/ijleal.v8.299

[20] Khubyari, L., \& Narafshan, M. H. (2016). A study on the impact of MALL (Mobile Assisted Language Learning) on EFL learners' reading comprehension. International Journal of English Language Teaching, 4(2), 58-69.

[21] Krivoruchko, V. A., Raissova, A. B., Makarikhina, I. M., Yergazinova, G. D., \& Kazhmuratova, B. R. (2015). Mobile-Assisted learning as a condition for effective development of engineering students' foreign language competence. International Education Studies, 8(7), 158-168. doi.10.5539/ies.v8n7p158

[22] Kukulska-Hulme, A. \& Shield, L. (2008). An overview of mobile assisted language learning: From content delivery to supported collaboration and interaction. ReCALL, 20(3), 271-289. doi.10.1017/S0958344008000335

[23] Kukulska-Hulme, A., \& Viberg, O. (2018). Mobile collaborative language learning: State of the art. British Journal of Educational Technology, 49(2), 207-218. doi.10.1111/bjet.12580

[24] Martin, F., \& Ertzberger, J. (2013). Here and now mobile learning: An experimental study on the use of mobile technology. Computers \& Education, 68, 76-85. doi.10.1016/j.compedu.2013.04.021

[25] Miangah, T. M., \& Nezarat, A. (2012). Mobile-assisted language learning. International Journal of Disturbed and Parallel Systems, 3(1), 309. doi.10.5121/ijdps.2012.3126

[26] Nariyati, N. P. L., Sudirman, S., \& Pratiwi, N. P. A. (2020). EFL pre-service teachers' perception toward the use of mobile assisted language learning in teaching English. International Journal of Language Education, 4(2), 38-47. doi.10.26858/ijole.v4i2.10052

[27] Nazari, M., \& Xodabande, I. (2020). L2 teachers' mobile-related beliefs and practices: Contributions of a professional development initiative. Computer Assisted Language Learning, 1-30. doi.10.1080/09588221.2020.1799825

[28] Nikolopoulou, K. (2020). Secondary education teachers' perceptions of mobile phone and tablet use in classrooms: Benefits, constraints and concerns. Journal of Computers in Education, 7(2), 257-275.

[29] Norris, C. A., \& Soloway, E. (2011). Learning and schooling in the age of mobilism. Educational Technology, 51(6), 3-10.

[30] Nuraeni, C. (2021). Maximizing mobile-assisted language learning (MALL) amid Covid-19 pandemic: Teachers' perception. Metathesis: Journal of English Language, Literature, and Teaching, 5(1), 11-18. doi.10.31002/metathesis.v5i1.3336

[31] Oz, H. (2015). An investigation of preservice English teachers' perceptions of mobile assisted language learning. English Language Teaching, 8(2), 22-34. doi.10.5539/elt.v8n2p22

[32] Prensky, M. (2001). Digital natives, digital immigrants. On the Horizon, 9(5), 1-6. doi.10.1108/10748120110424816.

[33] Rahimi, M., \& Miri, S. S. (2014). The impact of mobile dictionary use on language learning. Procedia Social and Behavioral Sciences, 98, 1469-1474. doi.10.1016/j.sbspro.2014.03.567

[34] Rosa, J.D. (2016). Experiences, perceptions and attitudes on ICT integration: A case study among novice and experienced language teachers in the Philippines. International Journal of Education and Development Using ICT, 12(3), 36-49.

[35] Taj, I. H., Sulan, N. B., Sipra, M. A., \& Ahmad, W. (2016). Impact of mobile assisted language learning (MALL) on EFL: A meta-analysis. Advances in Language and Literary Studies, 7(2), 76-83. doi.10.7575/aiac.alls.v.7n.2p.76

[36] Yang, J. (2013). Mobile assisted language learning: Review of the recent applications of emerging mobile technologies. English Language Teaching, 67(7), 19-25.

Norah Alghamdi is an Assistant Professor of Teaching English as a Second Language at Albaha University. She received her MA in TESOL from Cleveland State University and Ph.D. in TESOL from Concordia University Chicago. Her research interests include Computer-Assisted Language Learning, Mobile-Assisted Language Learning, EFL teaching methods. 